\title{
ПЕРСПЕКТИВЫ ПЕРЕРАБОТКИ И ПРИМЕНЕНИЯ НЕФТЕСОДЕРЖАЩИХ И БИТУМОСОДЕРЖАЩИХ МАТЕРИАЛОВ ПРИ СТРОИТЕЛЬСТВЕ АВТОМОБИЛЬНЫХ ДОРОГ
}

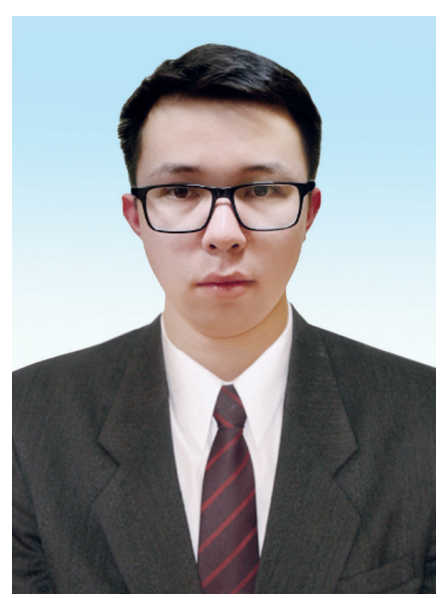

Н.Б. АСМАТУЛАЕВ, магистр технических наук, докторант ГИП Института КазНИиПИ «Дортранс», https://orcid.org/0000-00017562-7252

ТОО КАЗНИИПИ «ДОРТРАНС»

Республика Казахстан, 050000, г. Алматы, ул. Гоголя 84, а

Предложена и освоена новая технология реконструкции асфальтобетонных покрытий с использованием высокопроизводительных Ресайклеров RW - 2500, названного методом «холодного ресайклинга с добавкой самоцементирующих техногенных промышленных отходов». Создание монолитного «отражающего экрана» из старого асфральтового лома позволяет повысить категории дороги без полного вскрытия дорожной одежды.

Обосновано использование «отражающего экрана» в слое дорожной одежды для отражения остаточных деформаций снизу и восприятия вертикальных напряжений сверху для реконструкции дорожных конструкций без полного их вскрытия. Это позволяет наиболее эффрективно использовать ограниченные фринансы, выделяемые на восстановление дорожной сети, а также значительно продлить срок службы дорог. Эта технология также эффрективна для восстановления городских дорог, имеющих толстые слои асфральтобетона за счет традиционного ямочного ремонта с перекрытием новым слоем асфральтобетона. В городах можно сократить расход битума в 2-3 раза, так как толщина слоя асфральтобетона городских улиц достигает 0,5-0,7 м. Реконструкция автомобильных дорог методом холодного ресайклинка с повторным использованием асфральтового гранулята и безобжиговых вяжущих, на основе техногенных отходов имеет следующие

\footnotetext{
* Адрес для переписки. E-mail: boris-aisa@mail.ru
} 
преимущества: темпы строительства ускоряются в 1,5 раза, снижаются расходы новых материалов, а финансовые затраты на строительство и эксплуатацию автомобильных дорог снижаются в 2-3 раза, в зависимости от категории реконструируемых дорог.

КЛЮЧЕВЫЕ СЛОВА: автомобильная дорога, реконструкция, асфальтобетон, повторное использование, ресайклер, техногенные отходы, прочность, асфральто-минеральный бетон, эффрективность.

\section{АВТОМОБИЛЬ ЖОЛДАРЫН САЛУ КЕЗІНДЕ ҚҰРАМЫНДА МҰНАЙ ЖӘНЕ БИТУМ БАР МАТЕРИАЛДАРДЫ ҚАЙТА ӨНДЕУ ЖӘНЕ ҚОЛДАНУ ПЕРСПЕКТИВАЛАРЫ}

Н.Б. АСМАТУЛАЕВ, докторант, техника ғылымдарының магистрі, Қазғзжи «Дортранс» институты, https://orcid.org/0000-0001-7562-7252

«ДОРТРАНС» ҚАЗҒЗЖИ ЖШС,

Қазақстан Республикасы, 050000, Алматы қ., Гоголь к-сі, 84а.

Сондықтан жоғары өнімді техниканы қолдана отырып және қайталама ресурстарды қолдана отырып, ғылыми негізделген инновациялық технологияларды дамыту қажеттілігі туындайды, бұл жол құрылысының тиімділігін едәуір арттырады. RW - 2500 жоғары өнімді Ресайклерлерін пайдалана отырып, асфральтбетонды жабындарды қайта жаңартудың жаңа технологиясы ұсынылды және игерілді, бұл әдіс "өзін-өзі сәйкестендіретін техногендік өнеркәсіптік қалдықтарды қосумен суық ресайклине"әдісі деп аталады. Ескі ассральт сынықтарынан монолитті "шағылысатын экран" жасау жол төсемін толық ашпай-ақ жол санаттарын арттыруға мүмкіндік береді.

Жол конструкцияларын толық ашпай қайта құру үшін төменгі жағындағы қалдық деформацияларды көрсету және жоғарыдан тік кернеулерді қабылдау үшін жол төсемінің қабатында "шағылыстырғыш экранды" пайдалану негізделген. Бұл жол желісін қалпына келтіруге бөлінген шектеулі қаржыны тиімді пайдалануға, сондай-ақ жолдардың қызмет ету мерзімін едәуір ұзартуға мүмкіндік береді. Бұл технология асфральтбетонның жаңа қабатымен дәстүрлі шұңқырларды жөндеу арқылы асфральтбетонның қалың қабаттары бар қалалық жолдарды қалпына келтіру үшін де тиімді. Қалаларда битум шығынын 2-3 есе азайтуға болады, өйткені қала көшелерінің асфральтбетон қабатының қалыңдығы 0,5-0,7 м-ге жетеді.ассральт түйіршіктері мен өртенбейтін байланыстырғыштарды қайта қолдана отырып, суық ресайклинк әдісімен автомобиль жолдарын қайта құру техногендік қалдықтар негізінде келесі артықшылықтарға ие: құрылыс қарқыны 1,5 есе жеделдетіледі, жаңа материалдардың шығындары азаяды, ал автомобиль жолдарын салу мен пайдалануға арналған қаржылық шығындар қалпына келтірілетін жолдардың санатына байланысты 2-3 есе азаяды.

ТҮЙІн СӨзДЕР: автомобиль жолы, қайта құру, асфальтбетон, қайта пайдалану, ресайклер, техногендік қалдықтар, беріктік, асфральт-минералды бетон, тиімділік.

\section{PROSPECTS OF PROCESSING AND APPLICATION OF OIL- CONTAINING AND BITUMEN-CONTAINING MATERIALS IN THE CONSTRUCTION OF HIGHWAYS}

N.B. ASMATULAEV, doctoral student, Master of Technical Sciences, "Dortrans" Kazakh Research and Design Institute of Road Transport Problems, https://orcid.org/0000-0001-7562-7252

KAZR\&DI "DORTRANS" LLP

84a, Gogol str., Almaty, 050000, Republic of Kazakhstan 
A new technology for the reconstruction of asphalt concrete pavements using high-performance $R W$ - 2500 recyclers, called the method of "cold recycling with the addition of self-cementing manmade industrial waste", has been proposed and mastered. The creation of a monolithic "reflective screen" from old asphalt scrap makes it possible to increase the categories of the road without completely opening the pavement.

The use of a "reflective screen" in a layer of pavement to reflect residual deformations from below and the perception of vertical stresses from above for the reconstruction of road structures without their complete opening is justified. This makes it possible to effectively use the limited finances allocated for the restoration of the road network, as well as significantly extend the service life of roads. This technology is also effective for the restoration of urban roads with thick layers of asphalt concrete due to traditional pit repairs with overlapping with a new layer of asphalt concrete. In cities, it is possible to reduce bitumen consumption by 2-3 times, since the thickness of the asphalt concrete layer of city streets reaches 0.5-0.7 m. Reconstruction of highways by the method of cold recycling with the reuse of asphalt granulate and non-burnt binders based on man-made waste

KEY WORDS: highway, reconstruction, asphalt concrete, reuse, recycler, man-made waste, strength, asphalt-mineral concrete, efficiency.

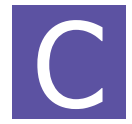

троительство и ремонт автомобильных дорог характеризуются высокими затратами на приобретение и доставку дорожно-строительных материалов, которые составляют до 70\% общих затрат. В то же время постоянно увеличивающаяся стоимость материалов и энергоресурсов приводит к еще большему увеличению стоимости дорожных одежд из асфальтобетона и его составляющих: битума, щебня, песка и минерального порошка. Использование дорожными организациями традиционных методов ремонта дорожных покрытий путем укладки нового слоя асфальтобетона поверх существующего в связи с высокими затратами становится неприемлемым и не всегда оправданным, так как не дает долговременного и качественного улучшения технико-эксплуатационных показателей покрытий. Вопрос снижения затрат на ремонт покрытия и повышения его качественных показателей является весьма актуальным. Альтернативой традиционному методу может быть использование нефтесодержащих и нефтезагрязненных пород и грунтов, а также материалов «старых» асфальтобетонных покрытий для их повторного применения при строительстве и ремонте автомобильных дорог.

На основе изысканий академика H.K. Надирова [1-6] и под его руководством впервые в Казахстане успешно реализована научно-техническая программа «Киры» (1980-1985 гг. с продлением на 1985-1990 гг.) - комплексный проект добычи и переработки нефтебитуминозных пород (далее НБП). Впервые в мире были разработаны и внедрены в практику строительства автомобильных дорог Казахстана технологии использования НБП как дорожного вяжущего для получения горячего и холодного асфальтобетонного покрытия. Построено более 7 тыс. км долговечных автодорог, что высоко оценили отечественные и зарубежные коллеги. Идея академика Надирова Н.К. об использовании НБП для производства дорожно-строительных материалов и на их основе строительства автомобильных дорог и послужило началом разработки технологии повторного использования материалов при реконструкции существующих асфальтобетонных покрытий в Казахстане [1-6]. Однако отсутствие в тот период требуемой дорожно-строительной техники сдерживало широкое использование разработки. Первые участки с повторным использованием асфальтового 
лома построены в 1998 году на автомобильной дороге «Алматы-Астана» участок «Гульшат-Акчатау». Для вскрытия и измельчения асфальтового покрытия использовали кулачковые катки и дисковые смесители

Метод снятия и переработки изношенного покрытия с его последующим использованием получил в последние годы широкое признание за рубежом: Германия, США, Япония, Франция, Чехия и др. используют повторно до 80-100\% асфальтового лома.

Проблемам разработки и повторного использования асфальтобетонов при строительстве и реконструкции автомобильных дорог посвящены работы В.Ф. Бабкова, Г.К. Сюньи, Л.Б. Гезенивея, Н.В. Горельиева, Г.С. Бахрах, Л.В. Билай, А.М. Алиева, B.В. Силкина и др. ученых [1].

В Казахстане до сих пор асфальтовый гранулят используют для второстепенных работ, общеизвестно, что асфальтобетон является ценным 100 \% возобновляемым дорожно-строительным материалом. Основным недостатком традиционных методов реконструкции и ремонта асфальтобетонных покрытий автомобильных дорог и городских улиц является то, что восстановление транспортно-эксплуатационных показателей покрытий обеспечивается за счет укладки новых слоев асфальтобетонных материалов. Таким образом, превращая существующие конструктивные слои дорожной одежды в «балласт», в котором бездействуют огромные запасы строительных материалов, обладающих всем комплексом свойств, присущим новым материалам. В этой связи особо важным следует считать направление исследований по разработке способов и технологий, обеспечивающих повторное использование материалов асфальтобетонных покрытий как наиболее ценного и дорогостоящего материала. Поэтому вызывается необходимость разработки научно обоснованных инновационных технологий с использованием высокопроизводительной техники и применением вторичных ресурсов, что позволит значительно повысить эффективность дорожного строительства. В Казахстане с 2002 года приобретены высоко-производительные ресайклеры для холодного фрезерования асфальтобетонных покрытий, толщиной до 50 см, и в настоящее время их количество составляет более 12 комплектов. Для холодного фрезерования асфальтобетонных покрытий предлагается большое количество фрез, отличающихся по ширине фрезерного барабана, мощности двигателя, глубине фрезерования и другим параметрам. В Казахстане используются самоходные ресайклеры RW - 2000 и 2500 фирмы «Wirtgen» (производство Германии), с шириной обрабатываемой полосы 2,0 - 2,5 м, которые получили широкое распространение при строительстве автомобильных дорог. При холодном фрезеровании асфальтобетонных покрытий ресайклерами гранулометрический состав полученного материала колеблется в широких пределах и зависит: от конструкции фрезерного органа, скорости вращения фрезерного барабана, рабочей скорости машины, глубины фрезерования, типа асфальтобетона (прочности) и других параметров. В то же время гранулометрия ресайклированного материала во многом определяет и влияет на такие свойства, как удобоукладываемость, уплотняемость, расход вяжущего для получения материала с требуемыми физико-механическими показателями [1]. Поэтому гранулометрия материала принята за основной критерий для оценки технических и технологических режимов работы ресайклера $\mathrm{RW}$ - 2500 при реконструкции асфальтобетонного покрытия на автомобильной дороге «Астана - Боровое». 
Таблица 1 - Факторы и их уровни в условном и натуральном масштабах

\begin{tabular}{|c|c|c|c|c|c|c|c|c|c|c|}
\hline \multirow[t]{2}{*}{$\begin{array}{c}\text { Наименование } \\
\text { факторов }\end{array}$} & \multirow[t]{2}{*}{$\begin{array}{l}\text { Усл. } \\
\text { обозн. } \\
\text { факт. }\end{array}$} & \multirow{2}{*}{$\begin{array}{l}\text { Ин- } \\
\text { декс } \\
\text { фак- } \\
\text { тора }\end{array}$} & \multirow[t]{2}{*}{$\begin{array}{l}\text { Ед. } \\
\text { изм. }\end{array}$} & \multirow[t]{2}{*}{$\begin{array}{l}\text { Сред. } \\
\text { уров. }\end{array}$} & \multirow[t]{2}{*}{$\begin{array}{l}\text { Шаг } \\
\text { варь- } \\
\text { иров. }\end{array}$} & \multicolumn{5}{|c|}{$\begin{array}{c}\text { Значения уровней факторов } \\
\text { и соответствующие } \\
\text { условные единицы }\end{array}$} \\
\hline & & & & & & -2 & -1 & 0 & +1 & +2 \\
\hline 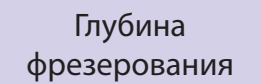 & $\mathrm{H}$ & $X_{1}$ & $C_{M}$ & 20 & 5 & 10 & 15 & 20 & 25 & 30 \\
\hline $\begin{array}{l}\text { Рабочая скорость } \\
\text { движения фрезы }\end{array}$ & $\mathrm{V}_{\mathrm{cp}}$ & $x_{2}$ & $\begin{array}{l}\text { M/ } \\
\text { мин }\end{array}$ & 5,09 & 0,71 & 3,67 & 4,28 & 5,09 & 5,8 & 6,51 \\
\hline $\begin{array}{c}\text { Прочность } \\
\text { асфальтобетона } \\
\text { покрытия }\end{array}$ & $\mathrm{R}_{\text {pact }}$ & $x_{3}$ & $\begin{array}{l}\mathrm{KrC/} \\
\mathrm{CM}^{2}\end{array}$ & 5 & 5 & 5 & 10 & 15 & 20 & 25 \\
\hline $\begin{array}{l}\text { Скорость } \\
\text { вращения } \\
\text { фрезерного } \\
\text { барабана }\end{array}$ & $V_{6}$ & $X_{4}$ & $\begin{array}{l}\text { Об/ } \\
\text { мин }\end{array}$ & 13 & 5 & 3 & 8 & 13 & 18 & 23 \\
\hline
\end{tabular}

Для оптимизации технологических и технических параметров фрезерования асфальтобетонных покрытий высокопроизводительными фрезами с целью получения наиболее однородных ресайклированных материалов в исследованиях использован метод математического планирования экспериментов [7] как наиболее эффективный метод для решения рецептурно-технологических задач.

Влияние технических и технологических параметров, в частности $\mathbf{n}$-факторов на гранулометрию ресайклированного материала может быть описана полиномом второго порядка:

$$
y=B_{0} X_{0}+\sum_{i>1}^{n} B i X i+\sum_{i<j}^{n} B i j X i X j+\sum_{i=1}^{n} B i X i^{2},
$$

Принятый рототабельный план второго порядка состоит из полного факторного эксперимента $2^{4}$, восьми звездных точек $(\alpha=2)$ и семи центральных. Факторы и их уровни в условном и натуральном масштабах сведены в таблице 1, а матрица планирования и расчетов - в таблице 2 .

После определения коэффициентов уравнения регрессии полинома второго порядка математическая модель модуля крупности гранулометрии ресайклированного материала в зависимости от четырех технологических и технических параметров принимает вид:

$$
M_{\kappa p}=-731,1+33,88 \mathrm{H}-0,58 \mathrm{H}^{2}+197,67 \mathrm{~V}_{\mathrm{cp}}-19,6 \mathrm{~V}_{\mathrm{cp}}^{2}+8,04 \mathrm{R}_{\mathrm{p}}-0,26 \mathrm{HR}_{\mathrm{p}}^{2}-3, \mathrm{~V}_{\sigma}-0,16 \mathrm{~V}^{2}{ }_{\sigma}
$$

С учетом вышеизложенного следует, что прочность асфальтобетона (от 0,5 до 2,5 МПа) практически не оказывает существенного влияния. По уравнению (2) были определены модули крупности ресайклированного материала (рисунок 1). 


\section{НЕФТЯНЫЕ БИТУМЫ}

Таблица 2 - Матрица планирования, результаты расчетов по модели

\begin{tabular}{|c|c|c|c|c|c|c|c|c|c|}
\hline \multirow[t]{2}{*}{$\begin{array}{c}\text { № } \\
\text { опыта }\end{array}$} & \multicolumn{4}{|c|}{$\begin{array}{c}\text { Факторы в условных } \\
\text { единицах }\end{array}$} & \multicolumn{4}{|c|}{$\begin{array}{c}\text { Факторы в натуральных } \\
\text { единицах }\end{array}$} & \multirow{2}{*}{$\begin{array}{c}\text { Модуль } \\
\text { крупн. } \\
M_{\text {кр расч }}\end{array}$} \\
\hline & $x_{1}$ & $x_{2}$ & $x_{3}$ & $X_{4}$ & $\mathrm{H}, \mathrm{CM}$ & $\mathbf{V}_{\phi-\text {-мин }}$ & $\mathbf{R}_{\mathrm{p} \mathrm{kr/ \textrm {cm }}}{ }^{2}$ & $\mathbf{V}_{\text {боб/мин }}$ & \\
\hline 1 & +1 & +1 & +1 & +1 & 25 & 5,80 & 20 & 18 & 3 \\
\hline 2 & -1 & +1 & +1 & +1 & 15 & 5,80 & 20 & 18 & 1,95 \\
\hline 3 & +1 & -1 & +1 & +1 & 25 & 4,28 & 20 & 18 & 3,05 \\
\hline 4 & -1 & -1 & +1 & +1 & 15 & 4,28 & 20 & 18 & 2,08 \\
\hline 5 & +1 & +1 & -1 & +1 & 25 & 5,80 & 10 & 18 & 3,09 \\
\hline 6 & -1 & +1 & -1 & +1 & 15 & 5,80 & 10 & 18 & 1,92 \\
\hline 7 & +1 & -1 & -1 & +1 & 25 & 4,28 & 10 & 18 & 3,04 \\
\hline 8 & -1 & -1 & -1 & +1 & 15 & 4,28 & 10 & 18 & 2,05 \\
\hline 9 & +1 & +1 & +1 & -1 & 25 & 5,80 & 20 & 8 & 3,15 \\
\hline 10 & -1 & +1 & +1 & -1 & 15 & 5,80 & 20 & 8 & 2,09 \\
\hline 11 & +1 & -1 & +1 & $\begin{array}{l}-1 \\
\end{array}$ & 25 & 4,28 & 20 & 8 & 3,14 \\
\hline 12 & -1 & -1 & +1 & -1 & 15 & 4,28 & 20 & 8 & 2,16 \\
\hline 13 & +1 & +1 & -1 & -1 & 25 & 5,80 & 10 & 8 & 3,15 \\
\hline 14 & -1 & +1 & -1 & -1 & 15 & 5,80 & 10 & 8 & 2,03 \\
\hline 15 & +1 & -1 & -1 & -1 & 25 & 4,28 & 10 & 8 & 3,16 \\
\hline 16 & -1 & -1 & -1 & -1 & 15 & 4,28 & 10 & 8 & 1,97 \\
\hline 17 & +2 & 0 & 0 & 0 & 30 & 5,09 & 15 & 13 & 3,42 \\
\hline 18 & -2 & 0 & 0 & 0 & 10 & 5,09 & 15 & 13 & 1,68 \\
\hline 19 & 0 & +2 & 0 & 0 & 20 & 6,51 & 15 & 13 & 2,49 \\
\hline 20 & 0 & -2 & 0 & 0 & 20 & 3,67 & 15 & 13 & 2,85 \\
\hline 21 & 0 & 0 & +2 & 0 & 20 & 5,09 & 25 & 13 & 2,66 \\
\hline 22 & 0 & 0 & -2 & 0 & 20 & 5,09 & 5 & 13 & 2,66 \\
\hline 23 & 0 & 0 & 0 & +2 & 20 & 5,09 & 15 & 23 & 2,82 \\
\hline 24 & 0 & 0 & 0 & -2 & 20 & 5,09 & 15 & 3 & 2,85 \\
\hline 25 & 0 & 0 & 0 & 0 & 20 & 5,09 & 15 & 13 & 3,00 \\
\hline 26 & 0 & 0 & 0 & 0 & 20 & 5,09 & 15 & 13 & 3,00 \\
\hline 27 & 0 & 0 & 0 & 0 & 20 & 5,09 & 15 & 13 & 3,00 \\
\hline 28 & 0 & 0 & 0 & 0 & 20 & 5,09 & 15 & 13 & 3,00 \\
\hline 29 & 0 & 0 & 0 & 0 & 20 & 5,09 & 15 & 13 & 3,00 \\
\hline 30 & 0 & 0 & 0 & 0 & 20 & 5,09 & 15 & 13 & 3,00 \\
\hline 31 & 0 & 0 & 0 & 0 & 20 & 5,09 & 15 & 13 & 3,00 \\
\hline
\end{tabular}

Из сопоставления результатов в соответствии с рисунком 1 и таблицей 2 следует, что оптимальными технологическими параметрами при фрезеровании асфальтобетонных покрытий являются следующие:

1. Рабочая скорость подачи фрезы - $4 \div 5,5$ м/мин;

2. Скорость вращения фрезерного барабана $10 \div 15$ об/мин;

3. При оптимальной глубине фрезерования в пределах 25-30 см достигается наибольшая однородность ресайклированного материала.

Для определения средней рабочей скорости фрезы разработан график в соответствии с рисунком 2, так как стремление к увеличению скорости не должно отражаться на качестве асфальтового гранулята. 


\section{НЕФТЯНЫЕ БИТУМЫ}

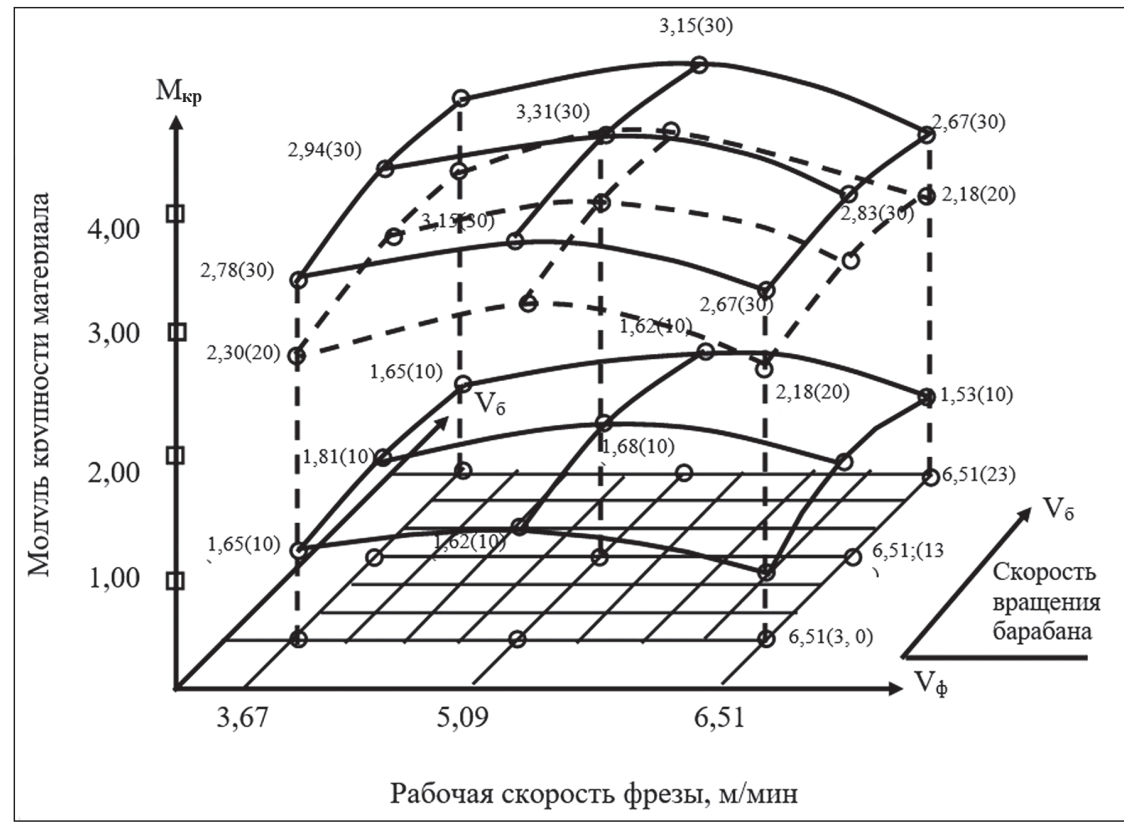

Рисунок 1 - Зависимость модуля крупности ресайклированного материала от технологических (скорости вращения фрезерного барабана и рабочей скорости фрезы) и технических (глубины фррезерования-Н) параметров фрезерования асфальтобетонных покрытий

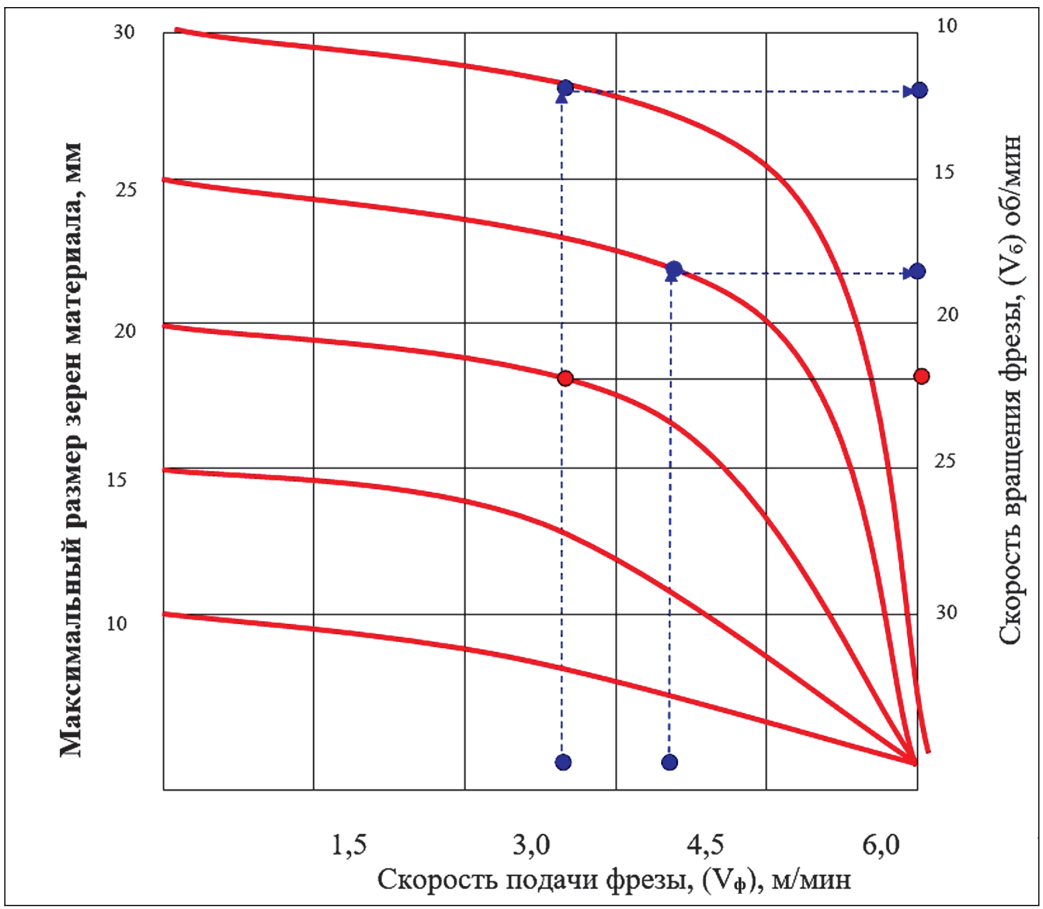

Рисунок 2 - График для предварительного выбора скорости подачи фрезы и скорости вращения фрезерного барабана в зависимости от максимального размера минерального материала в асфральтобетоне 


\section{НЕФТЯНЫЕ БИТУМЫ}

Выбрав скорость подачи фрезы и проведя вертикальные линии до пересечения с кривыми для определенных фракций каменного материала (например, для фракции 25-30 мм) на оси абсцисс получим предел регулируемой скорости (в данном примере предел скорости вращения фрезерного барабана составляет 13-18 об/мин) результаты испытаний различных составов органоминеральных материалов приведены в таблицах 3-5.

Цифры на верхних плоскостях - модуль крупности материала, в скобках - глубина фрезерования. Цифры на нижней горизонтальной плоскости - рабочая скорость фрезы в м/мин, в скобках - скорость вращения барабана, об/мин.

При реконструкции автомобильных дорог I-II1 технических категорий, на примере «Алматы-Бишкек» и «Астана-Боровое» асфальтобетонное покрытие, толщиной 18-20 см предлагается ресайклировать на толщину 20 см для его повторного использования в монолитном «отражающем экране». Ниже изображена схема расположения слоев дорожной одежды (рисунок 3). Ширина монолитного слоя устраивается шире нового покрытия за счет дополнительного введения шлаковых материалов и малых доз цемента.

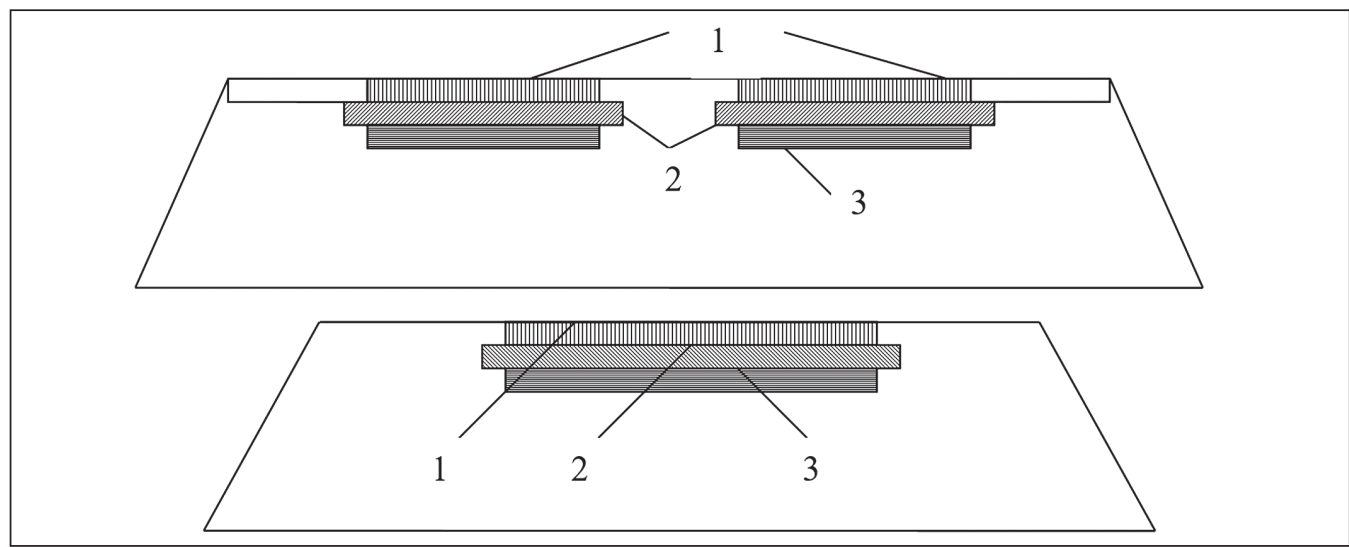

Рисунок 3 - Реконструкция асфальтобетонного покрытия на автодорогах I и III технических категорий без полного вскрытия дорожной одежды: 1 - новое асфальтобетонное покрытие;

2 - монолитный «отражающий экран» из асфальтового гранулята; 3 - основание существующей дорожной одежды.

Для устройства монолитных слоев выполнены экспериментальные исследования с отработкой производственных составов дорожных смесей при строительстве участков автомобильной дороги «Астана-Боровое». Результаты опытно-экспериментальных исследований приведены в соответствии с рисунками 4 и 5.

Для расчета вертикальных и отраженных напряжений в слое использованы формулы, предложенные профессором Смирновым А.В. [8].

$$
\sigma_{\text {пр } \mathrm{j}=}=\frac{2 g(t) \cdot e^{-h / 2 B}}{\left(1+\sqrt{\frac{E_{j t} \cdot \rho_{j+1}}{E_{j+1} \cdot \rho_{j}}}\right)} ; \quad \sigma_{\text {orp } \mathrm{j}=}=\frac{g(t) \cdot e^{-h / 2 B} \cdot\left(1-\sqrt{\frac{E_{j} \cdot \rho_{j+1}}{E_{j+1} \cdot \rho_{j}}}\right)}{1+\sqrt{\frac{E_{j} \cdot \rho j+1}{E_{j+1} \cdot \rho_{j}}}}
$$

где: j - число слоев; hj - толщина слоя; Еj - модуль упругости; рj - плотность; В длина контакта колеса с покрытием; g (t) - контактное давление от колес транспортных средств. 


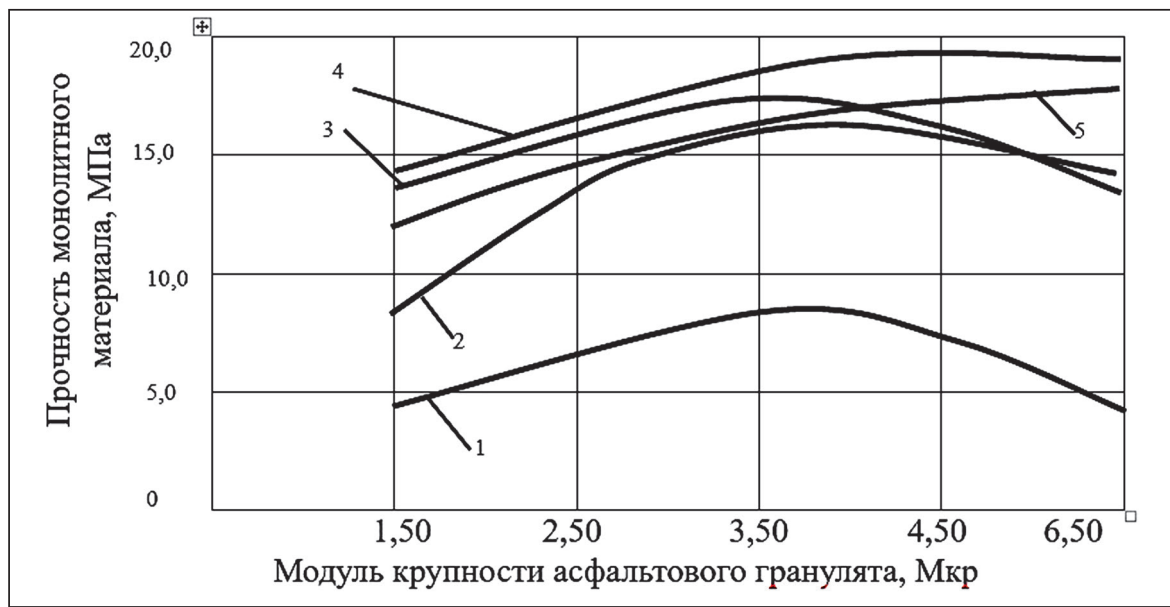

Рисунок 4 - Зависимость прочности монолитного асфальто-минерального бетона от модуля крупности асфальтового гранулята: 1-5 - количество шлакового вяжущего $8,12,15,20,25 \%$ от массы смеси

Контактное давление на плоской поверхности в течение времени $0<\mathrm{t}<\mathrm{T} 0$ с точностью до 5\% апроксимируется полиномом вида:

$$
\begin{aligned}
\mathrm{g}(\mathrm{t})=\mathrm{q} 0 & \left(0,649 \cdot \mathrm{t} \cdot \mathrm{V}-0,169 \cdot \mathrm{t}^{2} \cdot \mathrm{V}^{2}+0.022 \cdot \mathrm{t}^{3} \cdot \mathrm{V}^{3}-0,0155 \cdot 10^{-1} \cdot \mathrm{t}^{4} \cdot \mathrm{V}^{4}+\right. \\
& \left.+0,055 \cdot 10^{-3} \cdot \mathrm{t}^{5} \cdot \mathrm{V}^{5}-0.077 \cdot 10^{-6} \cdot \mathrm{t}^{6} \cdot \mathrm{V}^{6}\right)
\end{aligned}
$$

где: q0 - давление в шинах колеса; $\mathrm{T}_{0}=\frac{\mathrm{B}}{V}-$ время действия контактных давлений; В - длина контакта колеса с поверхностью; V - скорость горизонтального движения колесной нагрузки.

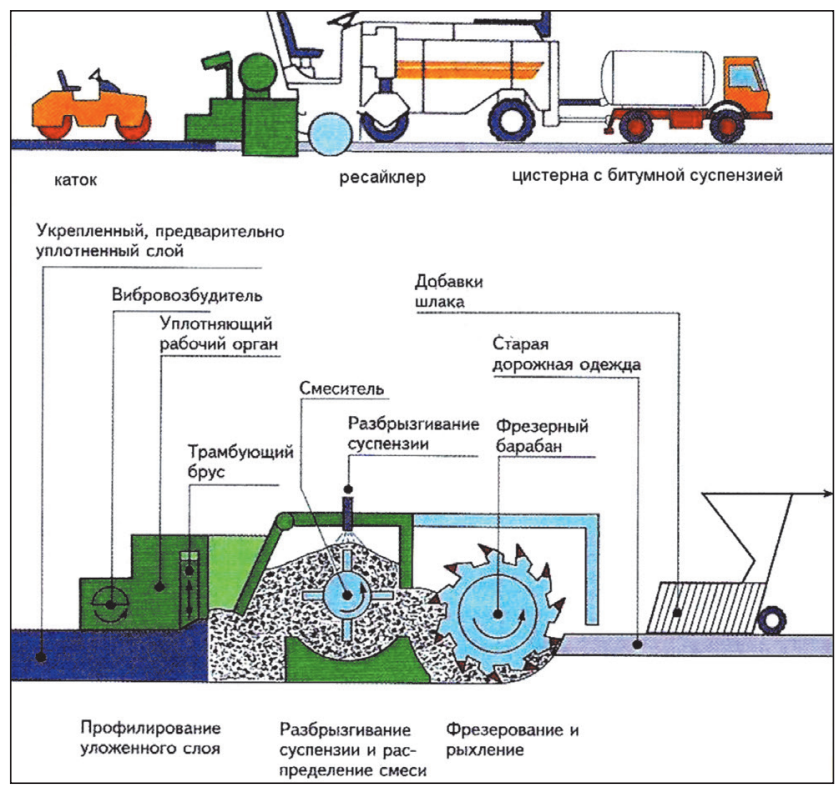

Рисунок 5 - Технологические операции при холодном ресайклировании асфальтобетонных покрытий с добавлением шлакового вяжущего 


\section{НЕФТЯНЫЕ БИТУМЫ}

Таблица 3 - Составы асфальто-минеральных смесей для монолитных дорожных оснований

\begin{tabular}{|c|c|c|c|c|c|c|c|}
\hline \multirow[b]{2}{*}{$\begin{array}{c}\text { № } \\
\text { состава } \\
\text { смеси }\end{array}$} & \multicolumn{7}{|c|}{ Используемые материалы в составе смеси, \% } \\
\hline & $\begin{array}{c}\text { Асфаль- } \\
\text { товый } \\
\text { гранулят }\end{array}$ & $\begin{array}{c}\text { Щебень } \\
\text { доменного } \\
\text { шлака } \\
\text { фр.5-20 }\end{array}$ & $\begin{array}{c}\text { щебень } \\
\text { доменного } \\
\text { шлака } \\
\text { фр.20-40 }\end{array}$ & $\begin{array}{c}\text { Шла- } \\
\text { ковое } \\
\text { вяжущее }\end{array}$ & Битум & Вода & $\begin{array}{l}\text { Акти- } \\
\text { ватор, } \\
\text { цемент } \\
\text { М-400 }\end{array}$ \\
\hline 1 & 40,0 & 10,0 & 30,0 & 20,0 & 2,0 & 3,0 & 2,0 \\
\hline 2 & 40,0 & 10,0 & 30,0 & 20,0 & 0 & 3,0 & 2,0 \\
\hline 3 & 30,0 & 20,0 & 30,0 & 20,0 & 2,0 & 3,0 & 2,0 \\
\hline 4 & 50,0 & 10,0 & 25,0 & 15,0 & 2,0 & 3,0 & 2,0 \\
\hline 5 & 50,0 & 10,0 & 25,0 & 15,0 & 0 & 2,0 & 2,0 \\
\hline 6 & 60,0 & 10,0 & 20,0 & 10,0 & 2,0 & 3,0 & 2,0 \\
\hline 7 & 70,0 & 10,0 & 15,0 & 5,0 & 2,0 & 3,0 & 2,0 \\
\hline 8 & 70,0 & 10,0 & 15,0 & 5,0 & 0 & 3,0 & 2,0 \\
\hline
\end{tabular}

Таблица 4 - Результаты испытаний образцов из асфальто-минерального бетона экспресс методом

\begin{tabular}{|c|c|c|c|c|}
\hline \multirow[t]{2}{*}{ № состава смеси } & \multirow[t]{2}{*}{ 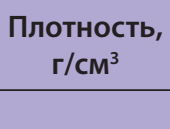 } & \multicolumn{3}{|c|}{$\begin{array}{c}\text { Прочность на сжатие образцов, } R_{c c^{\prime}} \text { MПа, } \\
\text { испытанных при температурах }\end{array}$} \\
\hline & & $0^{\circ} \mathrm{C}$ & $20^{\circ} \mathrm{C}$ & $50^{\circ} \mathrm{C}$ \\
\hline 1 & 2,22 & 3,56 & 2,15 & 0,78 \\
\hline 2 & 2,27 & 3,52 & 3,25 & 1,47 \\
\hline 3 & 2,31 & 3,48 & 2,27 & 0,79 \\
\hline 4 & 2,25 & 3,62 & 2,27 & 0,82 \\
\hline 5 & 2,24 & 3,51 & 3,35 & 1,51 \\
\hline 6 & 2,20 & 3,62 & 3,20 & 1,44 \\
\hline 7 & 2,21 & 3,68 & 2,18 & 0,72 \\
\hline 8 & 2,31 & 3,58 & 3,39 & 1,41 \\
\hline
\end{tabular}

Результаты, приведенные в таблище 4, свидетельствуют, что прочность при пропаривании обеспечивается только за счет асфальтового гранулята из-за медленного твердения гранулированного шлака, который в процессе набора прочности не участвует. Как видно из результатов испытания кернов (таблица 5), в условиях 2-3-х летней эксплуатации дороги активированные гранулированные шлаки в связи их использования без предварительного помола вступают в гидратацию и участвуют в процессах структурообразования бетона только за пределами 28 суток. Через 2 года прочность увеличивается в 2 раза, а через 3 года - более чем в 3 раза. Набор прочности будет продолжаться в течение многих лет, пока все крупные частицы шлака не прогидратируются [1-6].

В последнее время, благодаря заинтересованности в формировании устойчивых структур шлаковых бетонов [9-14], большое внимание уделяется наноразмерной модификации структуры $\mathrm{C}-\mathrm{S}-\mathrm{H}$ для создания гибридных, органических, цементирующих нанокомпозитов. Слоистая конструкция и склонность кремниевых цепочек к структурным дефектам в C-S-H [1,9-14] открывают возможность для введения разнообразных органических молекул в базовую структуру $\mathrm{C}-\mathrm{S}-\mathrm{H}$. Предложено три схемы для гибридизации или введения «гостевых молекул» в C-S-H. Первая схема интерполирует органические молекулы в слой C-S-H [1,9-14]. Поэтому использование гидравлически активных минеральных порошков с коллоидной структурой упрочнения обеспечивают асфальто-минеральным бетонам повышение прочности, с сохранением упруго пластичных свойств асфальтобетона $[1,7,15]$. 


\section{НЕФТЯНЫЕ БИТУМЫ}

Таблица 5 - Прочность кернов из асфальто-минерального бетона а/д «Астана - Боровое»

\begin{tabular}{|c|c|c|c|c|}
\hline \multirow{2}{*}{ Возраст образца } & \multicolumn{4}{|c|}{ Прочность на сжатие Rж, МПа, испытанных при $\mathrm{t}^{\circ} \mathrm{C}$} \\
\cline { 2 - 5 } & $\mathbf{2 0 ^ { \circ } \mathrm { C }}$ & $\mathbf{5 0 ^ { \circ } \mathrm { C }}$ & $\mathbf{0}^{\circ} \mathrm{C}$ & $-10^{\circ} \mathrm{C}$ \\
\hline 28 суток & $3,5-4,81$ & $2,1-2,29$ & $5,4-7,4$ & $6,2-7,9$ \\
\hline 2 года & $7,8-9,44$ & $2,6-3,32$ & $10,9-12,5$ & $16,7-18,6$ \\
\hline 3 года & $13,3-14,8$ & $4,2-5,22$ & $11,9-13,8$ & $19.5-22,5$ \\
\hline
\end{tabular}

Таблица 6 - Испытания образцов-кернов асфальто-минерального бетона после 3 лет эксплуатации дороги «Астана-Боровое» на морозостойкость

\begin{tabular}{|c|c|c|c|}
\hline \multirow{2}{*}{ Участки } & \multicolumn{3}{|c|}{ Прочность кернов в МПа, через 3 года эксплуатации } \\
\cline { 2 - 4 } & R сжатие, $\mathbf{2 0}^{\circ} \mathrm{C}$ & $\mathrm{R}$ раскол, $\mathbf{0}^{\circ} \mathrm{C}$. & Мрз, циклов \\
\hline 1 & 13,5 & 3,7 & 75 \\
\hline 2 & 15,4 & 5,1 & 100 \\
\hline 3 & 13,3 & 4,5 & 75 \\
\hline 4 & 14,1 & 4,9 & 75 \\
\hline 5 & 14,7 & 4,8 & 75 \\
\hline 6 & 18,1 & 5,1 & 100 \\
\hline Среднее & 14,8 & 4,7 & \\
\hline
\end{tabular}

Примечание. После МРЗ прочность асфальтобетона восстанавливается на 100\% через 30 суток выдерживания в нормальных условиях твердения.

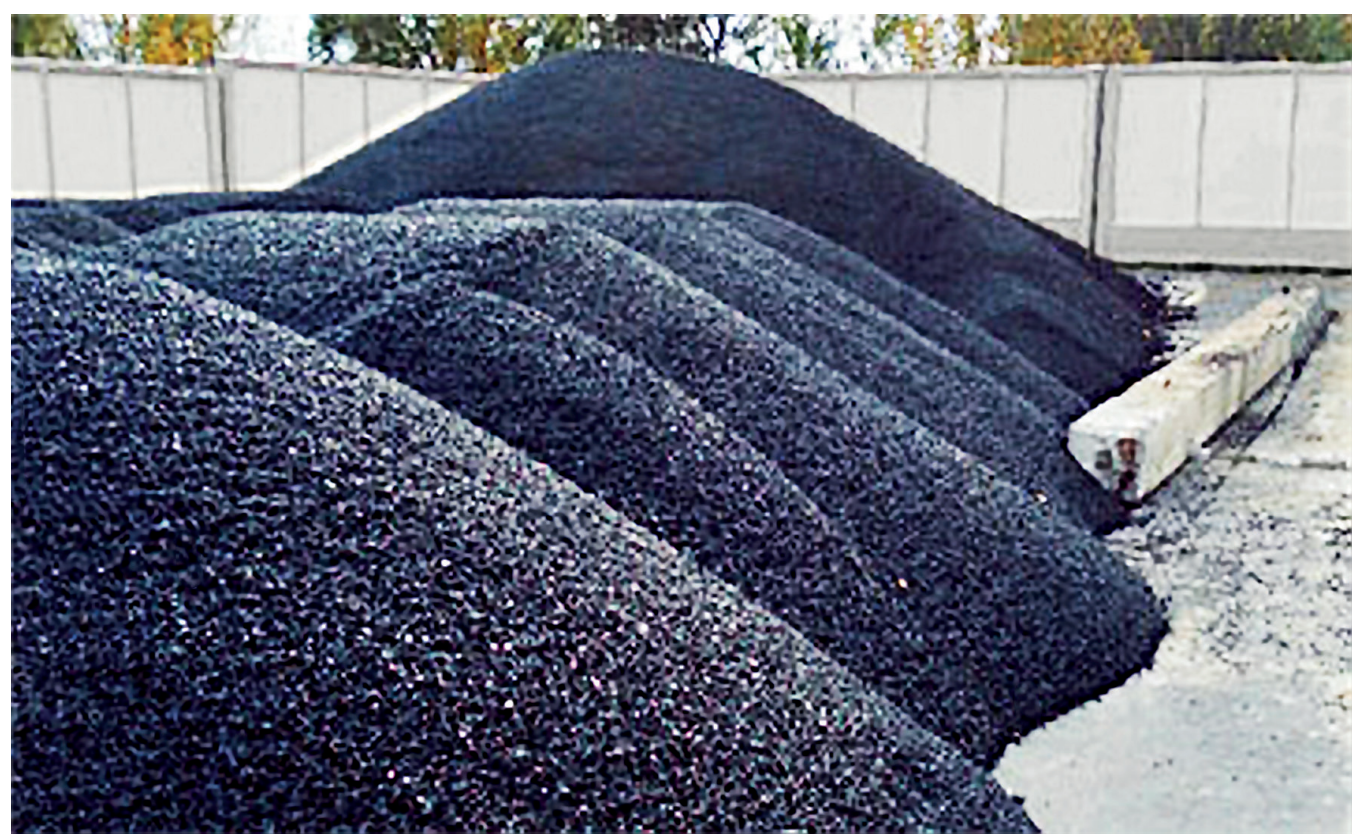

Рисунок 6 - Холодная асфральто-минеральная смесь не слеживается и не схватывается до уплотнения. Транспортируется на дальние расстояния 


\section{НЕФТЯНЫЕ БИТУМЫ}

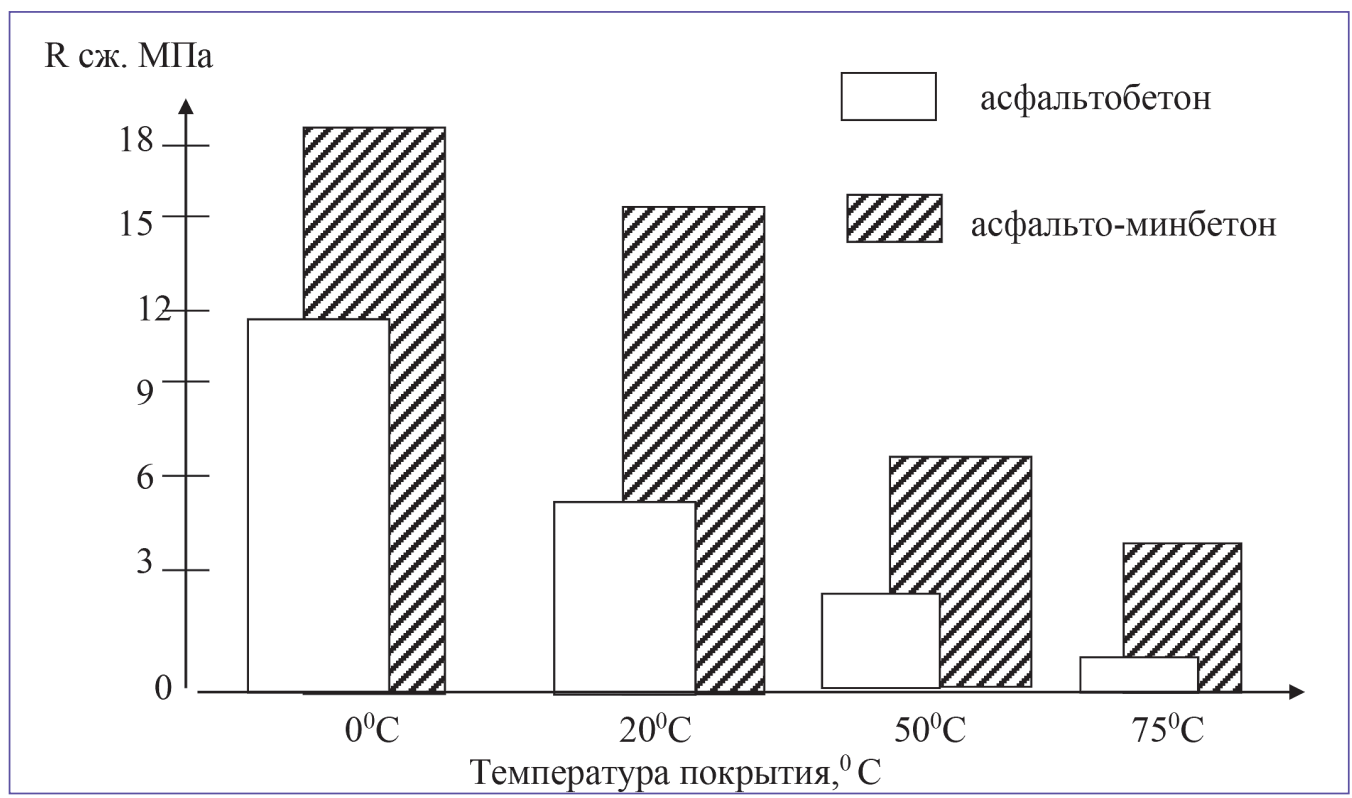

Рисунок 7 - Преимущества по прочности асфральто-минерального бетона от стандартного асфальтобетона при температурах покрытия
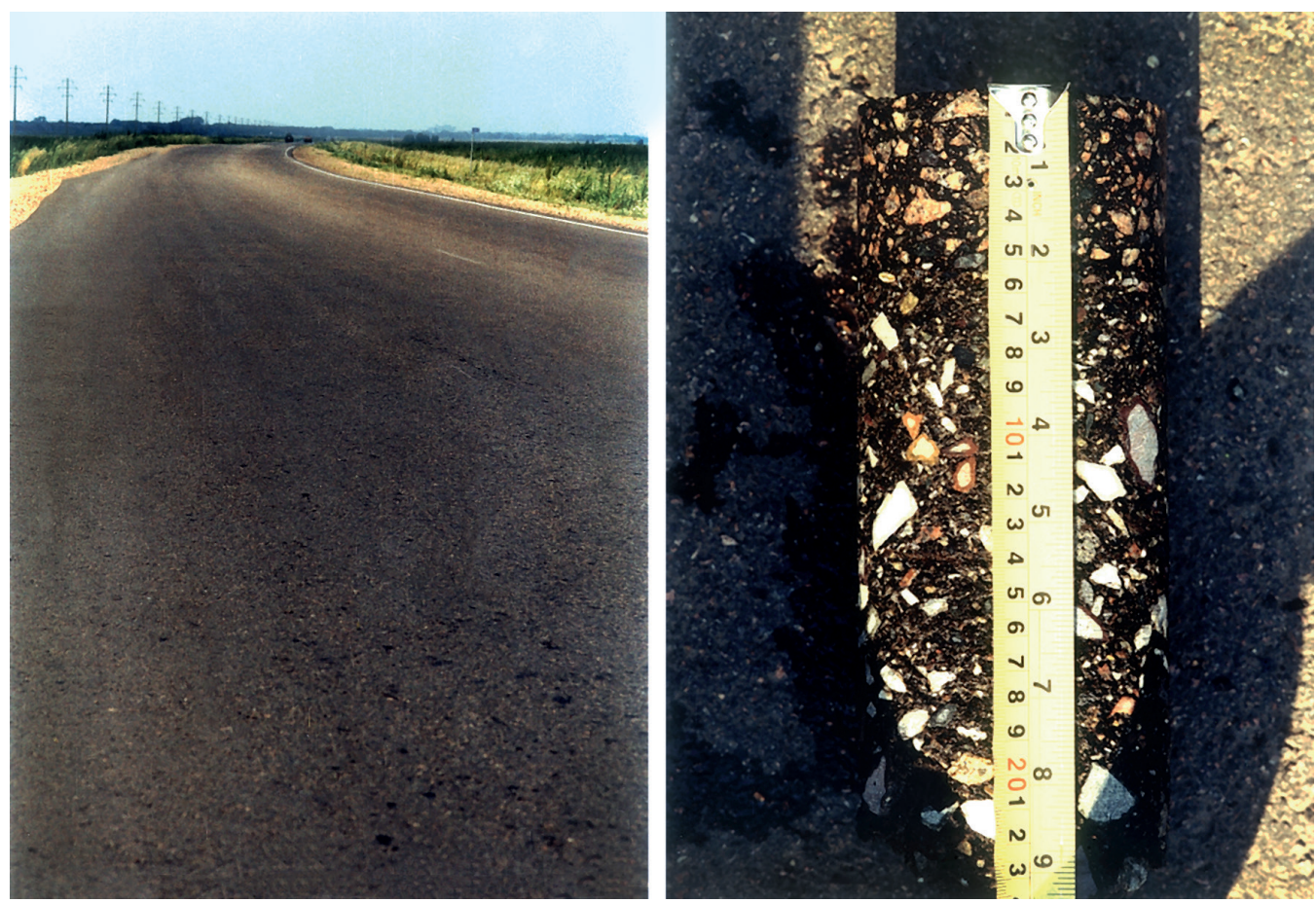

Рисунок 8 - Автодорога «Астана-Боровое», год строительства 2002 г., керн высверленный из асфальто-минерального бетона дороги (фото 2005 г.) 
На основе выполненных исследований предложены рекомендации и патенты по технологии реконструкции асфальтобетонных покрытий автомобильных дорог I-III технических категорий, а также городских и поселковых дорог [1-6,9-11, 15]. Под руководством академика Н.К. Надирова разработана научно-техническая программа «Разработать и освоить монолитное строительство дорожно-транспортных конструкций по мировым стандартам с комплексной переработкой промышленных техногенных отходов и вторичного сырья», согласованная МИИР РК и МОН РК на 2022-2024 годы. Реализация программы позволит освоить производство уникальных белитовых цементов и вяжущих и долговечных нанобетонов и асфальтобетонов на основе утилизации и переработки многотоннажных промышленных отложений, предусмотренных для строительства автомобильных, железных дорог и ИВПП аэродромов, в соответствии с законом «Зеленая экономика» Казахстана.

\section{Выводы}

1. Решена научно-техническая задача, имеющая важное народно-хозяйственное значение для дорожно-транспортной отрасли Казахстана, заключающаяся в разработке ресурсосберегающей технологии реконструкции асфальтобетонных покрытий с применением высокопроизводительной техники с повторным использованием асфальтового лома и многотоннажных техногенных отходов промышленности для восстановления дорожных конструкций автомобильных дорог без полного их вскрытия. Применение асфальто-минеральных бетонов прочностью в 3-4 раза выше стандартных асфальтобетонов позволит повысить срок эксплуатации дорог до 50 лет и снизить расходы дорогостоящих битумов и цементов.

2. Теоретически и экспериментально обоснованы технические и технологические параметры фрезерования асфальтобетонных покрытий высокопроизводительными ресайклерами для получения однородных по составу материалов.

3. Обосновано использование «отражающего экрана» в слое дорожной одежды для отражения остаточных деформаций снизу и восприятия вертикальных напряжений сверху для реконструкции дорожных конструкций без полного их вскрытия. Это позволяет наиболее эффективно использовать ограниченные финансы, выделяемые на восстановление дорожной сети, а также значительно продлить срок службы дорог. Эта технология также эффективна для восстановления городских дорог, имеющих толстые слои асфальтобетона за счет традиционного ямочного ремонта с перекрытием новым слоем асфальтобетона. В городах можно сократить расход битума в 2-3 раза, так как толщина слоя асфальтобетона городских улиц достигает 0,5-0,7 м.

4. Предложены оптимальные составы дорожных смесей на основе ресайклированных старых асфальтобетонных покрытий и гидравлически активных доменных, фосфорных шлаков, бокситового шлама и золошлаковых отходов 32 ТЭЦ Казахстана для создания монолитного «отражающего экрана» в слое дорожной одежды.

5. Экспериментальные исследования и результаты опытного строительства полностью подтвердили достоверность выполненных теоретических исследований. Экономическая эффективность разработок с использованием много тоннажных промышленных техногенных отложений, насчитывающих в отвалах, более 45 млрд тонн, с ежегодным ростом в 1 млн тонн, определяется снижением стоимости реконструкции и затрат на эксплуатацию автомобильных дорог, в течение 50 лет в 2-3 раза. 


\section{ЛИТЕРАТУРА}

1 Асматулаев Б.А. Строительство дорожных одежд с повторным использованием материалов реконструируемых дорог. ТОО «Эверо», Алматы, 1999. - 210. с. [Asmatulaev B.A. Construction of road clothes with reuse of materials of reconstructed roads. Evero LLP, Almaty, 1999. - 210 p.]

2 Предварительный патент №16297 РК. Композиция для покрытия автомобильных дорог и аэродромов / Асматулаев Б.А., Надиров Н.К., Асматулаев Р.Б., Пшембаев М.К. и др. Опубл. 2005. Бюлл. № 10. [Predvaritel'nyj patent №16297 RK. Kompoziciya dlya pokrytiya avtomobil'nyh dorog i aerodromov / Asmatulaev B.A., Nadirov N.K., Asmatulaev R.B., Pshembaev M.K. i dr. Opubl. 2005. Byull. № 10.]

3 Предварительный патент № 16413 РК. Сероасфральтобетонная смесь / Асматулаев Б.А., Надиров Н.К., Асматулаев Р.Б., Пшембаев М.К. и др. Опубл. 2005. Бюлл. № 11. [Predvaritel'nyj patent № 16413 RK. Seroasfal'tobetonnaya smes' / Asmatulaev B.A., Nadirov N.K., Asmatulaev R.B., Pshembaev M.K. i dr. Opubl. 2005. Byull. № 11.]

4 Инновационный патент № 18277 РК. Способ строительства автомобильных дорог / Асматулаев Б.А., Асматулаев Р.Б., Надиров Н.К. и др. / Опубл. 2010. Бюлл. № 2. [Innovacionnyi patent № 18277 RK. Sposob stroitel'stva avtomobil'nyh dorog / Asmatulaev B.A., Asmatulaev R.B., Nadirov N.K. i dr. Opubl. 2010. Byull. № 2.]

5 Инновационный патент №29382 РК. Способ переработки нефтесодержащих пород и/или нестезагрязненных материалов / Асматулаев Б.А., Асматулаев Р.Б., Надиров Н.К., Асматулаев Н.Б., и др. Опубл. 2014. Бюл. №12. [Innovacionnyj patent №29382 RK. Sposob pererabotki neftesoderzhashchih porod i/ili neftezagryaznennyh materialov / Asmatulaev B.A., Asmatulaev R.B., Nadirov N.K., Asmatulaev N.B. i dr. Opubl. 2014. Byul. №12.]

6 Инновационный патент № 4871 РК. Способ строительства дороги с использованием фррезерованного асфральтового гранулята / Асматулаев Б.А., Асматулаев Р.Б., Асматулаев Н.Б., Бессонов Д.В. и др. Опубл. 2020. Бюл. №16. [Innovacionnyj patent № $4871 \mathrm{RK}$. Sposob stroitel'stva dorogi s ispol'zovaniem frezerovannogo asfal'tovogo granulyata / Asmatulaev B.A., Asmatulaev R.B., Asmatulaev N.B. i dr . Opubl. 2020. Byul. №16.]

7 Веденяпин Г.В. Общая методика экспериментального исследования и обработка опытных данных. - М.: Колос, 1967. - C. 159 [Vedenyapin G.V. General methodology of experimental research and processing of experimental data. - M.: Kolos, 1967. - P. 159]

8 Смирнов А.В., Агалаков Ю.А. Расчет толщины асфральтобетонных покрытий на жестком основании по условиям сдвига // Наука и техника в дорожной отрасли. - 1977. -№ 1. - C. 23-25. [Smirnov A.V., Agalakov Yu.A. Calculation of the thickness of asphalt concrete coatings on a rigid base under shear conditions // Science and Technology in the road industry. - 1977. - No. 1. - Pp.23-25.]

9 Инновационный патент РК №29852. МЮ РК. Самовосстанавливающийся дорожный бетон / Асматулаев Б.А.. Асматулаев Р.Б., Чумаченко В.И., Асматулаев Н.Б., Асматулаев Ф.Б. Бюл. №5, 2015. [Innovative patent of RK No.29852. MJ RK. Self-healing road concrete / Asmatulaev B.A.. Asmatulaev R.B., Chumachenko V.I., Asmatullaev N.B., Asmatulaev F.B. Byul. No. 5, 2015. ]

10 Асматулаев Б.А., Асматулаев Р.Б., Турсумуравтов М.Т.. Асматулаев Н.Б. Самовосстанавливающиеся дорожные бетоны // Наука и техника в дорожной отрасли. - 2016. - №2. - C.18-22. [Asmatulaev B.A., Asmatulaev R.B., Tursumuravtov M.T. Asmatulaev N.B. Self-healing road concrete // Science and Technology in the road industry. -2016. - No. 2. - S. 18-22.] 
11 Р РК 218-134-2017. Рекомендации по строительству и реконструкции автомобильных дорог и искусственных взлетно-посадочных полос аэродромов из укатываемого дорожного бетона на основе безобжиговых вяжущих. МИИР РК КАД, ТОО КазНИиПИ «Дортранс, Астана. 2017г. С. 36. [R RK 218-134-2017. Recommendations for the construction and reconstruction of highways and artificial runways of airfields from rolled road concrete based on non-burnt binders. MIIR RK KAD, KazNliPI Dortrans LLP, Astana. 2017. p. 36.]

12 Абланов Б.Ф., Белоусов Б.В., Асматулаев Б.А. Исследование вещественного состава и кинетики твердения вяжущего на основе фосфорного шлака. Вопросы металлогении, вещественного состава и геологического строения месторождений Казахстана. - Алматы, 1978, Вып. 13. - С. 69-75. [Ablanov B.F., Belousov B.V., Asmatulaev B.A. Issledovanie veshchestvennogo sostava i kinetiki tverdeniya vyazhushchego na osnove fosfornogo shlaka. Voprosy metallogenii, veshchestvennogo sostava i geologicheskogo stroeniya mestorozhdenij Kazahstana. - Almaty, 1978, Vyp. 13. - S. 69-75.]

13 Sanchez F, Zhang L., Ince C.. Multi-scale performance and durability of carbon nanofiber/ cement composites In: Bittnar Z, Bartos PJM, Nemecek J, Smilauer V, Zeman J, editors. Nanotechnology in construction: proceedings of the NICOM3 (3rd international symposium on nanotechnology in construction). Prague, Czech Republic; 2009, p. 345-50.

14 Jennings H.M., Bullard J.W., Thomas J.J., Andrade J.E., Chen J.J., Scherer G.W. Characterization and modeling of pores and surfaces in cement paste: correlations to processing and properties // J Adv Concr Technol. - 2008. - № 6(1). P. 5-29.

15 Инновационный патент №6701 РК. Наноструктурированный минеральный порошок и наноструктурированный асфальтобетон / Асматулаев Б.А., Асматулаев Р.Б., Чумаченко В.И., Асматулаев Н.Б., Исламов В.А., Бессонов Д.В. От 18.03.2021 [Patent of RK No. 6701. Nanostructured mineral powder and nanostructured asphalt concrete / Asmatulaev B.A., Asmatulaev R.B., Chumachenko V.I., Asmatullaev N.B., Islamov V.A., Bessonov D.V. Dated 03.18.2021.] 